\title{
Historicidad, Juridicidad y Para-Literatura: En torno a Francisco de Vitoria (1486-1546) ${ }^{1}$
}

\author{
Fernando Gómez
}

Stanford University

Este artículo analiza la obra de Francisco de Vitoria (1486-1546), uno de los intelectuales más influyentes de la primera modernidad transatlántica, en especial los cursos universitarios llamados Relecciones Indianas; se estudia la historiografía vitoriana completa y se recrean algunas efemérides con respecto a su posible legado histórico dentro y fuera de la España de Primo de Rivera, así como los supuestos de conocimiento de nociones como historia, literatura y derecho (o cultura represiva). Se propone el concepto de "para-literatura" en relación a algunos de los problemas hermenéuticos que acarrea, para los lectores de hoy, este saber iusnaturalista normativo, de procedencia monástica, y de práctica universitaria, no libresca, de "oídas", y algunas de las tensiones entre la forma y el contenido, función social y repercusiones de los principios (o "títulos") de derecho que tienen que ver con el expansionismo de Occidente y la colonización de América.

PAlabras Clave: Francisco de Vitoria, derecho internacional, literatura, colonización, guerra justa, indios, América Latina, Península Ibérica, siglo dieciséis, Hispanismo.

This article focuses on the Spanish Dominican Francisco de Vitoria (1486-1546), one of the most influential intellectual figures in the Early Modern transatlantic world, specifically on his Salamanca University courses commonly called Indian Lectures. This article engages with the complete bibliography on Vitoria. It recreates a few official celebrations in memory of the possible historical legacy inside the Spain of Primo de Rivera and outside. The epistemic assumptions of Early Modern and colonial history, literature and law (or the repressive culture) are analyzed. The notion of "para-literature" is proposed to thus take into account hermeneutic problems generated, for contemporary readers today, by this monastic and university-based construction of an expansive natural-law normativity that is parallel to the already existing book and print technologies. We look into the form and content, social function and consequences of the official rationale or legal logic (so called "titles") of Western expansionism and the conquest and colonization of America.

KeYwords: Francisco de Vitoria, international law, literature, colonization, just war, Indians, Latin America, Iberian peninsula, Spain, the Sixteenth Century, Hispanism.

No es arriesgado aventurar que Francisco de Vitoria (1486-1546) es hoy uno de los muchos nombres invisibles que habitan el recuerdo de los

1 Versiones primerizas y parciales de este artículo se beneficiaron de la participación en Comparative Colonialisms: Preindustrial Intersections in Global Perspective organizado por el Center for Medieval and Renaissance Studies (CEMERS) en Binghamton University (31 de Octubre y 1 de noviembre de 1997), y el XXX11l Congreso del Instituto Internacional de Literatura Iberoamericana (Universidad de Salamanca, del 26 al 30 de junio del 2000). 
albores de la modernidad. El que fuera profesor de la Cátedra de Prima de Teología en la Universidad de Salamanca constituye actualmente una ausencia tan acostumbrada como inexplicable dentro de cursos universitarios en las humanidades de aquí y de allí. Y tal vez sea debido, esta viga en el ojo propio, a que nos las habemos con una de las figuras intelectuales más influyentes de la modernidad, cuya matriz, que aún nos incluye, es ya indisolublemente transatlántica: ${ }^{2}$ de ser un añadido primerizo y erudito en la tratadística del derecho internacional en autores norteamericanos como Henry Wheaton, ${ }^{3}$ Ernest Nys y Richard Francis Wright, ${ }^{4}$ la obra intelectual del dominico español ha pasado a habitar los olvidos que constituyen las discontinuidades propias de nuestra post-modernidad. ¿Y quién es el que se atreve a una travesía solitaria por estos textos tan áridos y tan precariamente atribuidos al dominico español? ¿En qué incentivos se apoyaría esta aventura? El signo "Vitoria" mal navega así, cual corcho flotante, ${ }^{5}$ entre océanos de desatención que involucran tanto a los historiadores de la Península Ibérica, no digamos de la Europa del Atlántico Norte ${ }^{6}$ que se viste de gala en los Estados Unidos, como a los pocos especialistas del derecho internacional y a los historiadores de las literaturas, a ambos lados del Atlántico, si es que alguno quedase.

A la sombra del debilitamiento de la necesidad de la diacronía, tengamos por cierto que a Vitoria se le conoce poco y mal. Su nombre se escucha, si es que se escucha, como quien oye llover la lluvia de los tiempos pasados;

2 El jesuita francés Teilhard de Chardin aporta hermosas panorámicas, en clave biológica, a esta “inexorable planetarización de la humanidad," The Future of Man, New York, Harper \& Row, 1964. Véase también su heterodoxa reformulación de lo cristiano o totalización siguiendo las pautas de esta convergencia o intensificación de energía evolutiva, The Heart of Matter, New York, Harcourt Brace Jovanovich, 1978.

3 Wheaton, Henry: Elements of International Law, editado por James Brown Scott, The Classics of International Law, a literal reproduction of the 1866 edition of Richard Henry Dana, edited by George Grafton Wilson (Washington: the Carnegie Institution [1836] n/d). Y también, History of the Law of Nations in Europe and America, from the Earliest Times to the Treaty of Washington, 1842, New York Gould, Banks, 1845, págs. 33-49.

4 De Indis et De Iure Belli Relectiones. Being Parts of Relectiones Theologicae Xll by Franciscus de Vitoria, Primary Professor of Sacred Theology in the University of Salamanca, with an introduction by Ernest Nys, Professor of International Law in the University of Brussels, and Dr. Herbert Francis Wright, Instructor of Latin in the Catholic University of America; edited by James Brown Scott, President of the American Institute of International Law, The Classics of International Law, Washington, the Carnegie Institution, 1917. Este volumen constituye una segunda edición "casi facsímil" de una edición anterior.

5 Véase un sumario útil en Truyol y Sierra, Antonio: Historia de la Filosofía del Derecho y del Estado. 2. Del Renacimiento a Kant, Madrid, Alianza Universidad, [1975] 1982, págs. 54-80.

6 Para esta norma, consultar Kelly, J.M.: A Short History of Western Legal Theory, Oxford, The Clarendon Press, 1992. 
lo cual se traduce en un excesivo respeto o una indiferencia grande que infectan no sólo al quehacer individual de Vitoria sino también al legado historiográfico, ineludiblemente internacional, que colma su recuerdo mayormente de parabienes. Podemos diferenciar dos afiliaciones mayoritarias: la tradición dominica asentada en suelo peninsular (Getino, Beltrán de Heredia, Urdánoz, Hernández-Martín) y la historiografía positivista norteamericana de principios del siglo veinte (J. B. Scott es el santo y seña dentro de los autores anteriormente citados). ${ }^{7} \mathrm{El}$ hispanismo británico, a la sombra de preocupaciones económicas, contribuye con un digno representante en M. GriceHutchinston. ${ }^{8}$ La versión de A. Pagden, ${ }^{9}$ y la edición con Lawrance, ${ }^{10}$ son hoy día el material más accesible y portátil. Las valoraciones de J.L. Abellán ${ }^{11}$ sobre la duda vitoriana, o su timidez epistémica, ${ }^{12}$ nos siguen pareciendo acertadas. Estas las enmarcamos dentro de la visión orteguiana sobre el nudo de duda y creencia que caracteriza la modernidad como crisis o ilegitimidad generalizada $;{ }^{13} \mathrm{o}$ lo que es lo mismo, no nos podemos desasir de "una tornasolada actitud" para con los principios del derecho, ${ }^{14}$ cuyo progresivo desdibujamiento no inhibe necesariamente unos procesos superlativos de planetarización, dominación y subordinación de continentes enteros. Hay toda una laboriosa reconstrucción por parte del Consejo Superior de Investigaciones Científicas digna de mención, que incluiremos más adelante.

La desaparición de Vitoria arrastra la de su circunstancia histórica para perjuicio de las miras de nuestra contemporaneidad. Es decir, la ausencia de esta norma reguladora (Vitoria) se debe ubicar en la realidad de atlántidas sumergidas de la Península Ibérica y el mundo americano dentro de una cronología que precede al XVlll (la Ilustración y la fundación constitucional de

7 Francisco de Vitoria and his Law of Nations, Oxford, The Clarendon Press, 1934.

8 Ensayos sobre el pensamiento económico en España, Madrid, Alianza Universidad, 1995.

9 The Fall of Natural Man: the American Indian and the Origins of Comparative Ethnology, Cambridge, Cambridge University Press, [1982] 1989, y The Languages of Political Theory in Early Modern Europe, Cambridge, Cambridge University Press, 1987.

10 Francisco de Vitoria. Political Writings, Cambridge, Cambridge University Press, 1991.

11 Historia Crítica del Pensamiento Español. Tomo ll: La Edad de Oro. Madrid, Espasa-Calpe, 1986.

12 Hay una hermosa posibilidad de acercamiento a la formulación de Abellán a través de las lecciones de Ortega y Gasset, "Ideas y Creencias (1940)," Obras Completas. Tomo V (193-1941), Madrid, Revista de Occidente, 1947. págs. 375-405.

13 Buscamos dar una concreción histórica a la intrigante formulación orteguiana sobre la ilegitimidad consubstancial de la modernidad. He tenido que consultar la versión inglesa, An Interpretation of Universal History, New York, Norton \& Company, 1973.

14 Véase al respecto "La idea del principio de Leibniz y la evolución de la teoría deductiva", Obras Completas. Tomo V1l1, Madrid, Alianza, 1983, págs. 63-121. 
los Estados Unidos), punto de partida, explícito o no, dentro y fuera de la práctica de las humanidades universitarias en los países hegemónicos (la Europa rica y los Estados Unidos en su versión oficial y estándar). Deseamos rescatar de los olvidos algunas incertidumbres y tensiones del "padre del derecho internacional" dentro del horizonte histórico de la primera modernidad transatlántica (modernidad o proto-capitalismo colonizador de América). ${ }^{15}$ Lo que queremos es poner en danza las nociones de historicidad (o plasticidad, transformación o cambio de la forma humana), juridicidad (mundo de la regulación o cultura represiva) y literatura (o la forma de la letra), al mismo tiempo que nos desdecimos de las celebraciones banales y arcaizantes que las cercan, a menudo implícitas en reivindicaciones de bienestar y progreso para una $\mathrm{u}$ otra singularidad nacional. Vitoria significa, al menos para nosotros, la complicidad del iusnaturalismo neotomista con posicionamientos histórico-sociales no exentos del ejercicio de la fuerza y del disfrute del privilegio. Nos las habemos aquí con unas primeras negociaciones entre novedad americana y racionalidad teológico-jurídica, con mecanismos formales de dominación y subordinación producidos por el monasticismo dominico en ámbitos universitarios cosmopolitas, y finalmente, ¿cómo no?, con los quehaceres colectivos y los dilemas interpretativos e historiográficos de una "literatura" vitoriana "de oídas," sin libros, ni escritura ni lectura propiamente dichas, sin apelaciones a la originalidad o la singularidad. ¿Qué sería "americanizar" a Vitoria sino traerlo a la vida de los vivos?

Entre tantos olvidos, ¿que sería esto sino intentar imaginar la amplísima dimensión vital, existencial, hermenéutica de los "indios" y las Relecciones Indianas inscritas en los cursos académicos del 1537-38 y 1538-39 dictados en la hora más temprana e importante (prima) dentro de la articulación de saberes más reputada (teología) en la Universidad de Salamanca, una de las casas de saberes más prestigiosas de la primera modernidad transatlántica? ¿Subalternidad en los aledaños de la norma? ¿Cómo imaginar la expresividad en el mundo del derecho? Es decir, la historización de esta lógica jurídico-represiva - la norma u ortodoxia de subordinación americana dentro de una convergencia de pautas eurocéntricas

15 Para esa labor de rescate crítico de la dimensión que podemos llamar el Atlántico trans-hispánico, véanse Anghie, Anthony : "Francisco de Vitoria and the Colonial Origins of International Law," Laws of the Postcolonial, Ann Arbor, The University of Michigan Press, 1999, págs. 89-107; Mignolo, Walter D.: "The Many Faces of Cosmo-Polis: Local Histories, Global Designs and Border Thinking" en Public Culture, vol. 12, núm. 3, Fall 2000, págs. 721-748. 
y modalidades para-literarias- buscará el "suelo" en el aire del exceso consubstancial o su paralogismo propio de su tiempo histórico (paralogismo, o surplus vital de todo raciocinio). ${ }^{16}$ Es decir, el pensamiento prestigioso de Vitoria - en su tiempo, no en el nuestro- no atrapa del todo la dimensión americana. ¿Cómo podría en verdad haberla atrapado? ¿Podemos nosotros aquí, hoy? La dimensión intercontinental de la colonización de América excedió, a buen seguro, la imaginación intelectual de nuestro dominico; como ciertamente el legado de su recuerdo, que intentaremos esbozar en estas páginas, excede todo esfuerzo individual, el nuestro incluido. Paralogismo, o incertidumbre, acompaña así por lo tanto ineludiblemente todo esfuerzo racionalizador o regulador de lo que puede llegar a constituir la realidad humana, necesariamente mudable (si la racionalidad es criatura histórica lábil, raramente grácil, los "productos" de ésta - las certezas o creencias, pero también los agujeros de las dudas- se ubican en la también móvil condición de la circunstancia vital, a la que se intentarán agarrar para transformar de una manera satisfactoria, coincidencia o felicidad; pero está fuera de duda que la coincidencia es sólo raramente posible en tiempos largos). Vitoria ejemplifica el razonamiento silogístico de la duda neotomista ante la inmensidad novedosa del continente americano. Esta duda ${ }^{17}$ no tiene por qué ser parálisis o inactividad, como bien ha señalado Mario Góngora. ${ }^{18}$

16 El que fuera catedrático de Historia del Derecho en la Universidad Autónoma de Barcelona, Jesús Lalinde Abadía, constituye para nosotros una fuente de inspiración fundamental. De él extraemos la equiparación entre represión y el derecho (i.e. cultura represiva). Muchos de sus numerosos artículos han sido publicados en Anuario de Historia del Derecho Español. Destacamos también sus obras Iniciación Histórica al Derecho Español, Barcelona, Ariel, 1970, y Las Culturas Represivas de la Humanidad (h. 1945), Zaragoza, Universidad de Zaragoza, 1992.

17 "Adriano Vl, por su parte, parece haber errado en pensar que si yo dudo de si esta guerra [con los Indios] es justa para el príncipe o si es justa la causa de esta guerra, la consecuencia inmediata es: Dudo si me es o no lícito ir a esta guerra. Confieso que de ninguna manera se puede obrar contra la duda de conciencia; y si dudo de si me es lícito hacer esto o no, peco si lo hago. Pero la consecuencia no es: Dudo de si es justa la causa de la guerra; luego dudo en consecuencia de si me es lícito pelear y pelear en esta guerra. La consecuencia es más bien la opuesta. Pues si dudo de si la guerra es justa, la consecuencia es que puedo ir a ella por orden de mi príncipe. Al igual que no es legítima esta consecuencia: El lictor duda de si es justa la sentencia del juez; luego duda de si le es lícito ejecutar la sentencia. La consecuencia es absolutamente inválida, es más, sabe que está obligado a ejecutar la sentencia de su superior. (...) [L]os súbditos no están obligados ni deben examinar las causas de la guerra, sino que pueden seguir en ella a su príncipe, confiados en la autoridad del príncipe y del Consejo público;" Palabras de Vitoria, incluidas en la Relectio de Iure Belli o Paz Dinámica, edición de Luciano Pereña, Madrid, CSIC, Escuela Española de la Paz, 1981, págs. 157 y 185. Todas las citas referentes a la segunda relección se refieren a esta edición, salvo que se indique lo contrario.

18 "[L]a inseguridad y la actitud [de incertidumbre] frente al problema de la legitimidad de la adquisición de las Indias no impidieron en absoluto la [expansión]". El Estado en el Derecho Indiano: Epoca de Fundación (1492-1570), Santiago de Chile, Instituto de Investigaciones Histórico-Culturales, 1951, págs. 98-9. 
América se "escapará" necesariamente de las lecciones americanistas del dominico español, tal vez de una manera similar a cómo la modernidad se escabullirá de la legitimidad, cualquiera que ésta se atreviera a ser, en la formulación desconcertante de Ortega y Gasset. En torno a las incertidumbres de Vitoria, que también debemos entender como objeciones para Carlos V (1500-1558), nos centraremos en las dos relecciones, De Indis [Sobre los Indios Americanos] y De Indis Relectio Posterior, sive de Iure Belli (Sobre los Indios Americanos o el Derecho de Guerra). Nuestra lectura pretende la crisis - o averiguación — de estos apretados supuestos o nudos casuístico-neotomistas de duda y certeza. Esta crisis intercontinental se llama, para Vitoria, las Indias Occidentales, indisolubles ya de la Península Ibérica. Las resoluciones, pero también las irresoluciones, de algunas de estas crisis constituyen la herencia de esta individualidad intelectual, aparentemente dada a la controversia. ${ }^{19}$ América "no cabrá" en las formulaciones neotomistas por más que Vitoria se empeñe (como si la racionalidad neotomista — la hermenéutica hegemónica, monástico-universitaria floreciente en el dieciséis transatlántico - fuera del todo insuficiente ante los vertiginosos cambios del sistema-mundo capitalista, en cuya matriz nos encontramos aún todos los habitantes del siglo veintiuno). Debemos estirar esta negativa: esta condición de "no cabida" o de no aprehensión, dentro y fuera de la cultura represiva, es para nosotros punto de toque fundamental para lo que sigue a continuación: la exploración de los acoplamientos y desavenencias entre historicidad y textualidad a propósito del drama intelectual de Vitoria (por supuesto, a su arrimo van sus exégetas, éste que suscribe incluido). La cultura represiva - el núcleo hegemónico de la ciudad letrada - no "cabe" enteramente, tampoco, en la forma de la letra (o literatura). Dicho a la inversa, la forma letrada no basta para explicar el fenómeno normativo de horma de vida-mundo que significa Vitoria, enmarcado en un horizonte monástico de suprema oralidad. En plata: la vida no es sólo literatura, algo que incluso los dados a las bellas, y las no tan bellas, letras tienen que admitir, aunque sea a regañadientes. Al respecto de la siempre parda y limitada vitalidad de las letras para la administración de la sociedad, tenemos que tener en cuenta también los posibles juegos de combinaciones de lo

19 Lu Ann Homza califica a Vitoria de "controvertido al respecto de las poblaciones americanas," Religious Authority in the Spanish Renaissance, Baltimore, The Johns Hopkins University, 2000, pág. 58. Curiosamente, la crítica que Homza atribuye a Vitoria sobre Erasmo de Rotterdam, en los debates de Valladolid de 1527, es que la hermenéutica de éste "deja al lector lleno de dudas" (pág. 58), como si dudar fuese índice de flaqueza, actitud vital denigrante. 
propio y lo ajeno (los deícticos: el aquí, hoy, el ahí, ayer, el allí, hace tiempo de la dimensión histórica y su relevancia para los proyectos de futuro; y también las cercanías, medianías y lejanías de lo mío, lo tuyo, lo suyo, etc.), a propósito de prácticas de conocimiento que se pueden llamar, siquiera tentativamente, hispanismo internacional o "trasterrado", en la formulación de Gaos. Las panorámicas de ayer y de hoy son ciertamente inquietantes, tal vez incluso prometedoras.

\section{Efemérides varias a propósito de Vitoria}

El rastreo pormenorizado de la historiografía vitoriana debería deparar algunas perplejidades. Es fácil constatar una persistente oficialidad de la figura de Vitoria que arranca, en el siglo veinte, en la dictadura de Primo de Rivera, pasa por los tiempos del franquismo y sus exiliados, ${ }^{20}$ y llega hasta algunos actos oficiales presididos por el actual rey de España, Juan Carlos I. Es como si cierto Vitoria contentase a todas las partes políticas habidas y por haber. Ha habido fundaciones, anuarios y efemérides varias. ${ }^{21}$ Al dominico español se le han erigido bustos y estatuas conmemorativas aún en pie dentro y fuera de Salamanca (por lo que el uso del pretérito perfecto parece justificado). ${ }^{22}$ Se han pintado murales con su figura ${ }^{23} \mathrm{y}$, que sepamos, hay al menos una universidad privada en las cercanías de Madrid

20 Homenaje a Fray Francisco de Vitoria y la Escuela Española, Montevideo, Universidad de la República, 1986.

21 Urdánoz menciona algunas de éstas, Obras de Francisco de Vitoria: Relecciones Teológicas, Madrid, Biblioteca de Autores Cristianos, 1960, págs. 70-74.

22 Ramón Hernández menciona el busto de Vitoria en las Naciones Unidas en Nueva York, obra de Francisco de Toledo, entregado en nombre de España por Juan Carlos 1 el 4 de junio de 1976. El busto de Vitoria en el Palacio de la Unión Panamericana de Washington es obra de Victorio Macho y fue entregado en nombre de España por el ministro de Asuntos Exteriores don Fernando María Castiella el 8 de octubre de 1963, Francisco de Vitoria: Vida y pensamiento internacionalistas, Madrid, Biblioteca de Autores Cristianos, 1995.

23 La edición de Relectio de Indis. Carta Magna de los Indios, estudios de Luciano Pereña, traducción de C. Baciero, corrección de F. Maseda, Madrid, CSIC, 1989, incluye reproducciones de los murales del artista español José María Sert en el Palacio de la Sociedad de Naciones en Ginebra. La sección hispana en la Pan-American Union se las ingenió para producir varias publicaciones. Entre ellas, Las Relecciones de Indis y de Iure Belli de Fray Francisco de Vitoria, O.PÁG. fundador del Derecho Internacional, Washington, 1963. Aquí se incluye la proclamación de la Vll Conferencia Internacional Americana celebrada en Montevideo, Uruguay (23 de diciembre de 1933) y noticia de la ubicación de una estatua de Vitoria, esculpida por Victorio Macho y donada por la Universidad de Salamanca, en el edificio central de dicha institución en Washington. Todas las citas referentes a la primera relección se refieren a esta edición de 1989, salvo que se indique lo contrario. 
que lleva su nombre. No pocas publicaciones ${ }^{24}$ lo vinculan con una apología formalista de los derechos humanos promulgados por las Naciones Unidas. ${ }^{25}$

No resistimos la tentación de incluir una descripción sumaria de una de estas efemérides, que nos dará un marcado sabor de época. Tuvo ésta lugar por partida doble en Madrid y Salamanca en 1923 con motivo de la venida a España de una Delegación de la Sociedad "Grotius" de Holanda ${ }^{26}$ por tratarse del cuarto centenario del jurista holandés y la donación de dos medallas conmemorativas por parte de dicha Sociedad a la Real Asociación de Jurisprudencia de la Corte y a la Universidad de Salamanca. Se hacía así de Vitoria un pariente mayor del jurista de los Países Bajos. El 22 de abril de 1923 tuvo lugar un acto solemne en la Universidad de Salamanca, presidido por importantes autoridades del momento. Se encontraban allí presentes el ministro de Instrucción Pública, Dr. don Eduardo Callejo de la Cuesta, el entonces ministro de Estado, don José María de Yanguas Messía, el profesor don Rafael Altamira, el ministro plenipotenciario del Uruguay don Benjamín Fernández y Medina y el encargado de negocios de los Países Bajos, señor Hubrecht, dando la bienvenida oficial a los representantes de la Sociedad "Grotius". Se pronunciaron elevados discursos en el paraninfo de la Universidad a cargo del profesor de Derecho Internacional, don Isidro Bato Sala, el ministro de Uruguay (quien presentó el proyecto de fundación de la Asociación Francisco de Vitoria), el rector de la Universidad, Dr. don Enrique Esperabé de Arteaga, el representante de la Sociedad "Grotius", señor Treub, y el ministro de Educación Pública, señor Callejo. Estas declaraciones celebraron, entre otras cosas, "la avanzada de los beneméritos soldados de la paz (Vitoria, Soto, Suárez, Bañez y Ayala" (pág. 14), las "reglas generales, tratado completo de la guerra y de la paz,

24 Por ejemplo, por partida doble en Hernández, Martín: Francisco de Vitoria; Vida y Pensamiento Internacionalistas, ibidem, y Derechos Humanos en Francisco de Vitoria. Antología, Salamanca, Convento de San Esteban, Biblioteca Dominicana/4, 1984, y Ocaña García, Marcelino: El Hombre y sus Derechos en Francisco de Vitoria, Madrid, Ediciones Pedagógicas, 1996.

25 Un paseo por el Centro Cívico de San Francisco, lugar fundacional conmemorativo de las Naciones Unidas, normalmente habitado en días soleados por mendigos, alcohólicos y dementes variopintos de todos las razas, nos dará datos elocuentes sobre estas negligencias institucionales, los papeles mojados y las insuficiencias de las letras, tal vez enteramente muertas, sobre los derechos de lo humano. Véase "Subalternity and International Law: The Problems of Global Community and the Incommensurability of Difference", Otto, Dianne: Laws of the Postcolonial, Ann Arbor, the University of Michigan Press, 1999, págs. 145-180.

$26 \mathrm{El}$ fragmento que sigue está extraído del Anuario de la Asociación Francisco de Vitoria, Vol. 1, Madrid, CSIC, 1927-1928. La numeración de las citas se refiere a éste. 
[la] formulación [por Vitoria] de un derecho de gentes perfectamente en armonía con el estado actual de la ciencia, [y de los] principios [definidos por Vitoria en sus Relecciones 'De Indis' y que son] aceptados por todos y repetidos en los más solemnes tratados, [y que ya] han pasado a constituir la parte dogmática e indiscutible del Derecho Internacional" (pág. 17). Fernández y Medina mencionó que "Vitoria habló para su tiempo y para su patria en lenguaje de verdad, con doctrina de cristiana y humana justicia, aun sabiendo que sus lecciones iban contra los más poderosos intereses políticos y privados de la Monarquía y de los hombres fuertes de la Conquista" (págs. 20-1). Enrique Esperabé calificó De Indis y De Iure Belli de "obra humanitaria" (pág. 26) y añadió "ante el problema de las nuevas razas de América, el maestro establece que es preciso conceder a estos pueblos un trato idéntico desde el punto de vista internacional, al que los demás en Europa gozan" (pág. 27). Terminado el acto académico, se organizó una procesión cívica hasta el Convento de San Esteban, donde el dominico Luis Alonso Getino disertó en latín. Al término de esta conferencia, el ministro de Instrucción Pública se dirigió hacia la lápida colocada en honor de Francisco de Vitoria y la descubrió en medio de los aplausos de la concurrencia. La lápida reza: "Al Maestro Fr. Francisco de Vitoria $(\dagger 1546)$. Glorioso patriarca del renacimiento intelectual salmantino y defensor acérrimo del derecho de gentes ("quem summum theologiae praeceptorum hispania dei singulari munere accepit," De Loc. Theol, Lib. Xlll, c.l.) en el Cuarto Centenario de su venida a Salamanca (1525). Firman esta lápida las Diputaciones regionales de Alava y Salamanca, la Universidad de Salamanca y el Convento de San Esteban, lugar de residencia de Vitoria. ${ }^{27}$

La cosa oficial no quedó ahí. Tres años después, el 14 de julio de 1926, se inauguró la Asociación Francisco de Vitoria "de carácter científico". El cuarto propósito de esta Asociación rezaba así: "honrar a los grandes pensadores, a los hombres ejemplares, por su ideas y su carácter, de nuestra raza; demostrar nuestra tradición jurídica, política y educadora, no inferior a otra alguna y en mucho superior a casi todas; fortificar la fé en nosotros mismos y preparar a las nuevas generaciones." El signo "Vitoria" se semantiza aquí como "la expresión de la justicia internacional, del amor

27 La inclusión de la Diputación regional de Alava se explica porque se creía que Vitoria indicaba la toponimia de procedencia del fraile. Parece asentado que esto no fue así y que el lugar de nacimiento es Burgos, aunque la fecha sigue oscilando años entre 1483 y 1486: Urdánoz, Obras..., págs. 2-3; Derechos Humanos en Francisco de Vitoria, pág. 17; y Frayle Delicado, Luis: Francisco de Vitoria, Madrid, Tecnos, 1998, págs. X-XI. 
de la paz y del respeto [a] los derechos humanos" (pág. 51). El ministro don Eduardo Callejo de la Cuesta firmó el 7 de marzo de 1927 la autorización de dicha Fundación y la inauguración de la Cátedra Francisco de Vitoria en la Universidad de Salamanca, cuyo primer curso sería dictado, ¿cómo no?, por Luis Alonso Getino (págs. 85 y ss.). El 11 de noviembre de 1927, se descubrió una segunda lápida al fraile dominico, aún visible en el Convento de San Esteban. El rector don Enrique Esperabé de Arteaga pronunció un discurso en el que hacía referencia "[a] las doctrinas del Maestro (...) [que] proclaman la igualdad de las razas y que defienden los principios eternos y de absoluta objetividad" (pág. 58), al mismo tiempo que se extendía en elogios para el General Primo de Rivera" (pág. 56). Se procedió entonces a la investidura de doctores "honoris causa" a los señores J.B. Scott, ${ }^{28}$ anteriormente citado, y Benjamín Fernández y Medina, embajador de Uruguay. El signo "Vitoria" significaba aquí, según este destacado hispanista y jurista, "[aquel que] vindicó noble y enérgicamente los derechos esenciales de la personalidad y de la naturaleza humana, la libertad personal, la libertad de conciencia, la propiedad privada, el derecho a su integridad y el autogobierno aún a las agrupaciones humanas de cultura más rudimentaria" (pág. 67). Un banquete siguió al discurso del Doctor Eduardo Callejo, ministro de Educación Pública. Más tarde, en el Convento de San Esteban, J. B. Scott y Fernández Medina depositaron ante la lápida conmemorativa un ramo de flores naturales (pág. 80). La jornada se cerró con una velada artística en el Liceo de la capital salmantina. La orquesta, dirigida por el maestro Bernat, interpretó la "sinfonía núm. 2 adagio-allegro de Hayden" (sic). Seguidamente, el coro de niñas del Convento de la Merced cantó una loa de salutación; la señorita Mantilla Herrero, ataviada con el traje típico charro, interpretó "Canción de Cuna," del maestro Ledesma; y nuevamente el coro de niñas de la Merced interpretó la popular canción "Muelos." La segunda parte de la velada vería la representación de la obra de Calderón de la Barca La Vida es Sueño (pág. 81). Al día siguiente, hubo un nuevo banquete en el Ayuntamiento de la ciudad. Las frases de los oradores, tal y como recoje

28 Las bases de datos atribuyen casi unas doscientas referencias a J.B. Scott. Su curriculum es amplísimo: cátedras de la Universidad de Heidelberg, profesor y decano de la Facultad de Derecho de varias Universidades Norteamericanas, entre ellas la Johns Hopkins University, delegado técnico de los Estados Unidos en la Conferencia de la Haya de 1907, fundador de la Sociedad Americana de Derecho Internacional y ya para 1927, secretario de la Fundación Carnegie y presidente del Instituto de Derecho Internacional. Es J.B. Scott hoy la tergiversación estándar de Vitoria como padre del derecho internacional en su vinculación doble a la doctrina Monroe y a los derechos humanos. 
el Anuario, fueron acogidas con gran entusiasmo por todos los comensales. Se dieron vivas a España, a América, a Portugal y a Salamanca (pág. 82). Una cita de Brown Scott sobresale entre otras:

“Tres siglos más tarde, lo que Vitoria había defendido con entereza es sostenido por el Presidente Monroe en su famoso mensaje de 1823, en el cual declara que el Nuevo Mundo no es susceptible de colonización. La doctrina de Monroe, especie de Evangelio inspirador de la política internacional [norte-]americana, era defendida tres siglos antes por un español que proclama el principio aún más valientemente que Monroe". ${ }^{29}$

Es así que entre vivas - $\mathrm{y}$ veras - se establece una continuidad ciertamente prodigiosa entre el iusnaturalismo neotomista de Vitoria del siglo dieciséis y la doctrina de Monroe (presidente 1817-1821, 1821-1825), activada por J.B. Scott. El conocido lema de "América para los americanos" proviene de Monroe. Claro que, ¿de qué América se está hablando aquí, sino de la paulatina hegemonía estadounidense en el período de entreguerra? Los intereses estadounidenses, a través de su portavoz J.B. Scott, vierten el viejísimo vino del derecho de gentes (o pluralidad de colectividades nacionales) proveniente de las ruinas medievales del Imperio Romano y la Patrística, según la reactualización a través de la modernidad neotomista vitoriana, en los odres nuevos de la formalidad o hegemonía estadounidense en la segunda mitad del siglo veinte, en cuyos coletazos aún nos encontramos. Estos esquemas coloniales son apreciables en referencia a la igualdad o utopía de una solidaridad internacional en organismos como Las Naciones Unidas (a la que todavía no hemos llegado; pensemos por ejemplo en el Tribunal Penal Internacional). ${ }^{30}$ ¿Pues no es Estados Unidos hoy la punta de lanza de eso que se da en llamar Occidente y dentro de lo cual "caben," más mal que bien, la dimensión histórica de la Península Ibérica y América Latina?

29 Para desoír los cantos de sirena del panamericanismo de J.B. Scott, conviene contextualizar la doctrina Monroe; ver Halperín Donghi, Tulio: Historia Contemporánea de América Latina, Madrid, Alianza, [1969] 1993, págs. 288-308; y Abernethy, David B.: The Dynamics of Global Dominance: European Overseas Empires, 1415-1980, New Haven, Yale University Press, 2000, págs. 84-87, 358.

30 Nuestra edición ha sido Documentos de Política Internacional, México, Secretaría de la Presidencia, Departamento Editorial, Recopilación y Prólogo de Manuel Tello y Renward García Medrano. Los 111 artículos de la Organización de las Naciones Unidas, firmados en San Francisco el 26 de junio de 1945, se encuentran en págs. 15-64. ¿No van éstos (¿siempre?) a la zaga de la madre de las naciones, la guerra? Nos encontramos uno de los Ortegas más vivos por estas mismas fechas; véanse con algún detenimiento sus palabras trasterradas en Buenos Aires (1940) y Lisboa (1944), "Sobre la razón histórica," Obras Completas. Tomo X11, Madrid, Alianza, 1983, págs. 147-330. También hemos consultado la versión en inglés, Historical Reason, New York, W.W. Norton, 1984. 
J.B. Scott no tenía por qué pecar de originalidad. Se limitaba a reproducir fielmente las versiones de sus antecesores, Wheaton y Wright. Derecho de gentes (o ius gentium) se traducirá así en el reconocimiento y equiparación sobre el papel de una multiplicidad de configuraciones nacionales. El objetivo: salvaguardar el libre comercio entre las naciones existentes (recordemos la hegemonía, para fechas de 1926, del Reino Unido, Francia y Alemania en Africa y Asia). La formulación del derecho de gentes era así furgón de cola del derecho de guerra, descontextualizado de las lógicas arcaicas del derecho natural y el derecho civil en la Patrística. Este derecho de gentes, inscrito entre naciones colonizadoras y colonizadas formal e informalmente en las fechas anteriores a los años 1960, formalizaba unas pretensiones de universalidad de colectividades nacionales, pero siempre serviles de los derechos de guerra, o remodelación de la "guerra justa" de la Patrística. Este mundo de vivas y de muertos en la Salamanca de abril de 1926 que hemos recreado anteriormente, nos permite ver, creemos que claramente, algunas de las interesadas lecturas que a propósito del signo "Vitoria" se ataban y desataban por parte de propios y extraños. Se da la no desinteresada confluencia internacionalista y pretendidamente igualitaria, al menos sobre el papel, de la doctrina Monroe y la panegírica peninsular del dominico por parte de las autoridades locales del momento. El hispanismo internacional de J. B. Scott, dado a las letras escasamente bellas del derecho, se apropiaba así, paulatinamente y entre festejos, del legado de Vitoria no por méritos meramente académicos sino por ocupar históricamente un lugar internacional de creciente poder y privilegio (entre otros, el vehículo raudo y cosmopolita del inglés). Esta es hoy la lectura habitual de Vitoria, precedente arcaico del nuevo orden internacional que va a surgir al final de la Segunda Guerra Mundial, sin lugar a dudas exégesis "bien intencionada" en el sentido estricto de que cuadra con los intereses creados de las naciones colonizadoras (en 1936, España ya no se encuentra entre éstas). Si el mundo moderno que Vitoria atisbaba era un mundo sorprendente, ineludiblemente internacional y transatlántico, el mundo de su exégeta estadounidense, J.B. Scott, ya con el ferrocarril, las máquinas de tracción, la telefonía, los telegramas y los aeroplanos, es ya un mundo de convergencia y de intensificación de energía humana en aras de la producción y consumo de mercancías. Nada humano quedará fuera de esta aldea global de aceleración de la producción. De lo que se trata es de domesticar los imprevistos de la novedad. ¿Se contagia hoy la alegría de estos vivas lanzados al aire en la Salamanca de la dictadura de 
Primo de Rivera? ¿Y cómo podían ver propios y extraños lo que se les avecinaba? ¿Damos nosotros vivas, en España o en América, a Vitoria? Si lo que nos interesan son las crisis y los avatares de las ubicaciones cambiantes de un hispanismo internacional, en relación con los dos tiempos histórico-vitales de la Europa de Vitoria y la América de J.B. Scott, mejor dejamos éstas para mañana.

\section{La Para-Literatura represiva Vitoriana}

Y es que la "cultura represiva"-digámoslo con el vocabulario de Lalinde-Abadía - en la que debemos insertar a Vitoria no se presta de buena gana a lecturas apresuradas, ni por su codificación textual árida, rigurosa y parcial, ni por su contenido enrevesado de racionalidad silogístico-teológica neo-tomista. ¡Difícil, si no imposible, buscar los acomodos a esta heterogeneidad hermenéutica! La institucionalización de esta práctica de ordenación de la realidad social sólo parcialmente se explica por la forma de la letra (alfabética) que hoy nos puede llegar, mayormente en español o en inglés y no en el original latino. Digámoslo así: la mediación de este saber no es cabalmente a través de la letra; el saber de Vitoria es sólo letrado tangencial o lateralmente y esto no por voluntad propia. Eso de "literatura moderna" resulta altamente resbaladizo dentro de un horizonte -el dieciséis - eminentemente para-textual, como corresponde a una sociedad analfabeta a ambos lados del Atlántico. Los incómodos "textos" de Vitoria pondrán a prueba las buenas ganas de los "lectores" contemporáneos, entre otras cosas porque, de no tener cuidado, podemos desnaturalizar las formas de comunicación en las que debió de haber existido Vitoria, quien no escribió nada de su puño y letra que nos haya llegado. A la manera de un McLuhan, el medio aquí tambien significa el mensaje. Repitamos: los textos de Vitoria que hoy pueden llegar a nuestras manos, pero nunca de una manera fácil o espontánea, deben trastocar las pretensiones de naturalidad de la singularidad libresca, los llamados a la originalidad de la creación por parte de un autor individual cuyo saber ha sido encerrado por los siglos de los siglos para propios y extraños en el bien mueble de formato cerrado más o menos accesible que llamamos "libro". La práctica hermenéutica monástico-universitaria de mnemotecnia ritualística tiene poco que ver, en verdad, con nuestras buenas o malas maneras de lector silencioso de libros viejos. El saber de Vitoria es, se dice pronto, cabalmente un saber no libres- 
co. Su erudición repudia toda singularidad. La sociabilidad que debemos imaginar para esta formalización de saberes oficiales dio una primacía al sentido del oído. ${ }^{31}$ Este es un teatro de la memoria en el aula académica que verá la grafía como un proceso repudiable que desvirtúa su esencial pulpa, y no sólo a nivel formal. ${ }^{32}$ El saber de Vitoria es de "suma o de depósito." Bebe de las fuentes de la Patrística, muy concretamente de San Agustín (354-430) y Santo Tomás de Aquino (originalmente inscritos en el siglo decimotercero). Es un saber de memoria larga, o de elefante. La conceptualización del derecho de guerra justa de Vitoria que veremos más adelante arranca de aquí. El renacimiento neotomista, frecuentemente singularizado en el dominico español, se yergue a la sombra temible del libro de Deuteronomio. Este no se queda remiso ante la coetánea brutalidad de El Príncipe (1513) de Nicolás Maquiavelo o el encomio de la mesura y la prudencia de la educación emblemático-alegórica de príncipes cristianos, por ejemplo en Saavedra y Fajardo (si recordamos los amables diálogos humanistas de Alfonso de Valdés y la Utopía (1515) de Tomás Moro, tenemos en un pañuelo una visión cabal de la literatura política más influyente del dieciséis). ${ }^{33}$ El saber vitoriano se atreve a formular, congruentemente dentro de su horizonte histórico merced a la posición de fuerza que ejerce el monasticismo dominico, unas pretensiones de universalidad bajo la explicitación de un cristianismo totalizante e intolerante en cuanto única verdad o creencia vivible y posible, también para las siempre sorprendentes Indias Occidentales.

Es decir, Vitoria no duda en hablar del orbe que se está abriendo ante los ojos de su imaginación sólo dieciocho años después de la conquista de Tenochtitlan por Hernán Cortés en 1521 (Vitoria tiene por entonces 35 años). El saber de Vitoria nunca será "existencialista", vivencial o de primera mano, de la realidad americana, y nunca lo pretenderá. Sería anacrónico imputar al silogismo racionalista neotomista unos supuestos de conocimiento que no eran los suyos. Nos las habemos en estas dos relecciones latinas con un saber que nunca "viaja" a través de la autoría de Vitoria, sino

31 Véase una cuidadosa sensibilidad para la rica geografía histórica de los saberes medievales aún pertinentes para el contexto histórico de nuestro dominico en Maravall, Jose Antonio: Estudios de Historia del Pensamiento Español, Madrid, Ediciones de Cultura Hispánica, 1967.

32 Para no arrodillarse y adorar al dios libro, y mucho menos para tratarlo como criatura transhistórica, véase Flor, Fernando de la: Biblioclasmo: Por una práctica crítica de la lecto-escritura, Salamanca, Junta de Castilla y León, Consejería de Educación y Cultura, 1997.

33 Enrique Dussel ha llegado a hablar del inicio de la modernidad en relación al maquiavelismo de Hernán Cortés, The Invention of the Americas: Eclipse of "the Other" and the Myth of Modernity, Nueva York, Continuum, 1995, págs. 38-48. 
a través de sus alumnos. Es a éstos a quienes les debemos tardía y marginalmente la mediación de la letra alfabética. Y nueva vuelta a la tuerca: la imprenta (las "letras de molde" en el lenguaje de la época) vendrá mucho después de la práctica letrada. Lo cual no hay que entender como indicio de debilidad, sino todo lo contrario (la administración de la sociedad transatlántica en el sistema de justicia subido al carro de la letra procesal encadenada no pasa tampoco por la imprenta). Recordemos que estamos proponiendo que Vitoria es la norma oficial y horma prestigiosa de lo que se entiende por saber para un mundo humano que está expandiéndose. Carlos V llega efectivamente a "arrimarse al banco" de las aulas salmantinas donde Vitoria expone su saber, en una tremenda señal de respeto sin precedentes en nuestra actualidad. ${ }^{34}$ Es decir, Vitoria evidencia la simbiosis para-literaria de saber universitario, teología y derecho, formulada en la lengua franca, el latín. ${ }^{35}$ Esta altura no-libresca y no-letrada formará la educación general básica — la norma, la horma, los requisitos mínimos- de los miembros de la nobleza alta o de medio pelo, por ejemplo de Vasco de Quiroga, ${ }^{36}$ y también, de hidalgos, soldados, letrados de mayores o escasos sesos, bachilleres y burócratas concienzudos o indolentes. Estos serán los que se llevarán a Vitoria - y no en formato de libro de bolsillo- junto con sus enseres y pertenencias a América. Vitoria es, por lo tanto, uno de los candidatos más conspicuos en esta condición de "bien mueble" intelectual en su modalidad auricular ineludiblemente vinculado, y no sólo temáticamente, con la colonización de América. La institución universitaria y sus aledaños político-burocráticos constituyen la circunstancia histórico-social inmediata que da cabida a la posibilidad siempre incierta de prácticas de conocimiento que pueden resultar, aunque no sea así en muchos casos, en textualizaciones en lengua latina, o en el más humilde español. Dentro de

34 Urdánoz incluye la necesaria contextualización, Obras..., págs. 41-53.

35 Para una deseable contextualización del período, ver Kagan, Richard: Students and Society in Early Modern Spain, Baltimore, The Johns Hopkins University Press, 1974. Véase, por supuesto, sobre todo, el tremendo esfuerzo de erudición de Gil Fernández, Luis: Panorama Social del Humanismo Español (1500-1800), Madrid, Tecnos, 1997.

36 Incluimos nuestro Good Places and Non-Places in Colonial Mexico: The Figure of Vasco de Quiroga (1470-1565), Maryland, University Press of America, 2001, para la contextualización del personaje. No hay evidencia escrita de un contacto directo entre Vitoria y Quiroga. Sí hay evidencia de un contacto indirecto a través de un discípulo del primero, fray Alonso de la Vera Cruz, quien reemplazará a Quiroga en Nueva España en el cuidado de sus pueblos-hospitales durante la estancia prolongada de éste en España (Mexican Architecture of the Sixteenth Century.Vol 1, de George Kubler, New Haven, Yale University Press, 1984, pág. 14). Truyol y Serra, Historia..., habla de una proximidad de la sensiblidad de Vitoria y Bartolomé de las Casas (págs. 70-75). Proponemos esta proximidad entre Vitoria y Quiroga (págs. 128-130, citas 55-6). 
estos amplísimos campos imaginarios de oralidad colectiva, ${ }^{37}$ ésta es una de nuestras generalizaciones fundacionales de esta investigación: el saber de Vitoria pretendía acotar o fundamentar, con mayor o menor fortuna, los principios jurídicos de expansión europea.

Vitoria busca desmentir algunas de las falacias que acechan un razonamiento legítimo (la etimología de "título" es precisamente esto). Limpiar, pulir y dar esplendor... Esta es la tarea de Vitoria siempre en relación con los principios de expansión europea. Su visión es eurocéntrica, ${ }^{38}$ claro, no podría ser otra cosa (y de nuevo es un disparate achacarle el anacronismo de la falta de un policentrismo jurídico del que el siglo veintiuno aún carece). Vitoria no puede concebir (¿podemos nosotros?) una realidad humana que no pase por los dictámenes eurocéntricos de la Cristiandad (hoy tal vez diríamos las teologías del capital). Vitoria — como buen intelectual dominico del dieciséis - se concentra en la racionalidad de los principios y los criterios de aplicabilidad dentro de la sociabilidad del monasticismo universitario, la ideología imperial de la modernidad que reaviva el derecho romano y los saberes escolásticos de los Padres de la Iglesia Cristiana en un mundo oficialmente cristiano. Estamos con una sociedad - la de Vitoria - que se concibe a sí misma como unidad en la creencia. No reconoce Vitoria la mera posibilidad de saberes no cristianos (las Relecciones Indianas no tienen nada de "indiano" en el sentido sugerido por nociones contemporáneas como transculturación o hibridez). No se trata de un saber, por lo tanto, que se deje atrapar permanentemente por las redes de lo plausible, lo verosímil o lo conjetural..$^{39}$ La cultura represiva puede, por supuesto, formular incertidumbres, pero intentará siempre, como objetivo último, desdecirlas, decirlas mejor a contrapelo de sus encontrados entendidos, domar a éstos. El quehacer intelectual vitoriano no tiene nada de entretenimiento. De lo que se trata, con o sin la participación posterior de la nueva tecnología de la imprenta, es de regular con vigor y rigor los mundos posibles de desconcertante vida humana que

37 Para una contextualización de algunas de estas prácticas (justas poéticas, arquitecturas efímeras, etc.) de este y otros períodos entre medias de oralidad y escritura, ver el inspirador trabajo de Egido, Aurora: Fronteras de la Poesía en el Barroco, Barcelona, Crítica, 1990.

38 Para algunas de estas panorámicas, conviene consultar Rabasa, José: Inventing America: Spanish Historiography and the Formation of Eurocentrism, London, University of Oklahoma Press, 1993.

39 Véase la tremenda erudición de Víctor Frankl para visiones encontradas de saber, El "Antijovio" de Gonzalo Jiménez de Quesada y las Concepciones de Realidad y Verdad en la época de la Contrarreforma y del Manierismo, Madrid, Ediciones Cultura Hispánica, 1963. 
están ya apareciendo con fuerza no en las islas de la mar océana, sino en la tierra firme tras $1521 .^{40}$

Queda para otro lugar la tarea de sortear el proceloso oceáno de fuentes escritas de Vitoria, sobre todo a través de sus hermanos de orden (Urdánoz, Getino y Beltrán de Heredia). Mención especial merece la labor de rescate emprendida por las ediciones del Consejo Superior de Investigaciones Científicas, bajo la dirección de Luciano Pereña. ${ }^{41}$ No nos podemos acercar aquí a los problemas hermenéuticos y metodológicos ${ }^{42}$ que conlleva esta fuerte heterogeneidad de cultura represiva que desprecia las letras de molde. ${ }^{43}$ Intentaremos seguidamente sintetizar una semántica de contenidos indianos fieles al saber no-heterodoxo de nuestro dominico español.

\section{La semántica de las Relecciones Indianas}

La primera Relección incluye dos secciones: una llamémosla "negativa", donde se expone la falacia de la presunta validez de algunos de los posibles argumentos legitimadores del expansionismo europeo en América, y una "positiva" donde otros se dan por buenos. La forma tripartita propia de la escolástica de la quaestio, que incluye la inicial presentación de argumentación falaz, la responsio a ésta y la confutatio, o conclusión, presenta, en el caso de estas dos Relecciones, al margen de posibles lagunas que se pueden achacar a copistas descuidados, el número idéntico de siete funda-

40 Aun sin "rozar la realidad (...), las conclusiones silogísticas de Vitoria [pasaron] a ser leyes en el consejo del monarca; ver Esquivel Obregón, T.: Apuntes para la Historia del Derecho en México, México, Porrúa, 1984, pág. 248. Véanse igualmente las panorámicas de la burocracia o juridicidad en el contexto novohispano, págs. 191-259, 300-324, 370-558.

41 Relectio de Indis. Carta Magna de los Indios, y Relectio de Iure Belli o Paz Dinámica: Escuela Española de la Paz. Primera Generación 1526-1560, corresponden a la primera y segunda Relección respectivamente. Se incluyen los nombres de Vidal Abril, Carlos Baciero, Antonio García y Francisco Maseda. La solapa de este segundo texto menciona el siguiente consorcio: la Universidad Pontificia de Salamanca, la Universidad Pontificia Comillas de Madrid, la Comisión Asesora de Investigación Científica y Técnica, el Comité Conjunto Hispano-Norteamericano para Asuntos Culturales y el Instituto de Cooperación Iberoamericana, dentro del programa de investigación "Violencia y guerra justa: Escuela Española de la Paz," iniciado bajo los auspicios de la Fundación Juan March.

42 Para algunas de estas posibilidades, véanse las varias historizaciones ofrecidas por Chartier, Roger: Forms and Meanings, Philadelphia, University of Pennsylvania Press, 1995.

43 El texto de Aurora Egido antes aludido es crucial para una historización de modalidades comunicales en el horizonte histórico que incluye a Vitoria. 
mentos de derecho no aceptables y siete aceptables. La coincidencia del siete, número mágico del Apocalipsis, por ejemplo, o Las Siete Partidas, de Alfonso X El Sabio, evidencia una presunción numerológica, incluso mesiánica que, existente en San Agustín, se trasvasa al racionalismo neotomista del dominico español (desconocemos si Tomás de Aquino participa de este mesianismo formalmente o en contenidos). En todo caso, el lector contemporáneo debe, si no quiere caer en el pozo negro de las meras contradicciones textuales, reacomodar la simetría expositiva de esta incómoda casuística, siquiera con la imaginación histórica. Es claro que este racionalismo doctrinal persigue una simetría sin fisuras entre planteamiento y conclusiones y que encuentra dicha simetría no ya deseable, sino humanamente inevitable. Dicho a la inversa, para la modernidad neotomista de Vitoria lo no simétrico no es enteramente humano.

La primera sección constituye, efectivamente, un recorte cierto de los poderes del Emperador y del Papa, lo cual se dice más pronto de lo que se asimila en relación al siglo dieciséis. Vitoria parece adoptar una postura conciliarista en los tiempos anteriores al Concilio de Trento (1545-1563), al que el dominico español no podría asistir por enfermedad. El orbe no pertenece sin cortapisas a los emperadores y papas, a pesar del universalismo del que se arrogan (recordemos que Clemente Vll corona a Carlos V Emperador del Sacro Imperio Romano Germánico en febrero de 1530). ${ }^{44}$ Vitoria desmiente que "los indios" no puedan ser, al menos formalmente, dueños de sus bienes (y debemos distanciarnos en cierta medida de la brutal homogeneización del nombre inapropiado de "indios" dentro de la heterogeneidad de poblaciones americanas). ${ }^{45}$ Precediendo con todo cuidado las deliberaciones de Valladolid (1542-3), para las cuales la legitimidad ya no es un problema, Vitoria amplía, en cierto sentido, las posibilidades de coexistencia, para tiempo corto, de ámbitos de creencia en tierras americanas. En ningún momento se pone en duda la singularidad del ideal de vida cristiano, históricamente intolerante e inflexible (ya hemos hecho referencia a

44 Pereña, L.: Relectio..., pág. 37. Resulta significativo señalar las tensiones entre los distintos vástagos resultantes de las ruinas del modelo imperial romano: el monasticismo y la Patrística, la revitalización de formas romanas, el entorno de Carlomagno ( el Sacro Imperio Romano) y la centralización formal de la cristiandad en el Papado. Maravall tiene unas sugerentes palabras sobre el brote letrado y el renacimiento del derecho romano patrocinado por Carlomagno, Estudios..., págs. 348 y siguientes.

45 Véase un convincente acercamiento a la riqueza y pluralidad de estas poblaciones americanas en la primera modernidad esbozada por Brotherston, Gordon: Book of the Fourth World: Reading the Native Americas through their Literature, Cambridge, Cambridge University Press, 1992. 
que estas relecciones se abrevan en el libro brutal del Deuteronomio). Sin embargo, Vitoria insiste en que aquellos que no participan inicialmente de la creencia del cristianismo (los herejes), no pueden perder sus bienes por motivo de su herejía, salvo que se mofen y causen injuria a la hegemónica unión cristiana de dicho y hecho (o fe), abarcadora ya de América. Está claro que la pluralidad de creencias americanas habrá de pasar, más pronto que tarde, por las horcas caudinas de una singularidad de creencia pública en un horizonte, no enteramente el nuestro, en el que la creencia importaba como factor fundamental de diferenciación social.

Desmitifica Vitoria un tanto la noción de "descubrimiento" (¿pues no estaban ya los indios allí?), al mismo tiempo que su razonamiento llega a desbrozar el brote de la intencionalidad ya como plausible argumento de derecho e ineludible factor motriz de la subjetividad moderna. ${ }^{46} \mathrm{La}$ primera Relección incluye el pasaje del voluntarismo, supuestamente exento de coacción para la aceptación, inevitable por otra parte en los supuestos de racionalidad y naturalidad, de un monoteísmo cristiano que se constituye como creencia oficial y excluyente (el ámbito de creencia cristiana y la racionalidad neotomista se suponen mutuamente interdependientes y totalizantes, es lo que podemos llamar el prejuicio racionalista del neotomismo del dieciséis). Las opciones no pueden ser muchas históricamente según nuestro descendiente de conversos. ${ }^{47}$ Entra así esta primera Relección en un terreno resbaladizo, donde "creer es un acto de voluntad" (pág. 92), pero donde no existe la posibilidad real de una pluralidad de opciones, ya que "[c]on blandura y no con dureza hay que apartarlos de la práctica habitual de sus ritos" (pág. 92). ${ }^{48}$ La persistencia en la infidelidad se castigará con la pena capital, no así la blasfemia (pág. 87). La guerra será lícita ante la persistencia de la antropofagia, el incesto (pág. 93), pero no contra fornicarios, ladrones o sodomitas (pág. 94).

La segunda parte de esta primera Relección expone los argumentos fundacionales de legítimo derecho para la ya irreversible expansión ibéri-

46 Fredric Jameson ("On the Sexual Production of Western Subjectivity; or, Saint Augustine as a Social Democrat"; inédito) ha tratado de algunas de las violencias constitutivas de esta subjetividad moderna, que se puede retrotraer a las ruinas romanas, el entorno del monasticismo, la vergüenza de la sexualidad, la disciplina confesional, etc.

47 El dato está en Gil Fernández, Panorama..., pág. 447.

48 Se puede entrar en juegos comparativos entre los indios y los moriscos desde el punto de vista oficial o jurídico. Ver el trabajo brillante de Márquez Villanueva al respecto de éstos, El Problema Morisco (Desde otras laderas), Madrid, Ediciones Libertarias, 1998. Debemos añadir que uno de los manuscritos de las Relecciones vitorianas, Valencia (1557), se encuentra en la biblioteca particular del Patriarca San Juan de Ribera en el Real Colegio de Corpus Christi (Pereña, pág. 89). 
ca en América. ¡Y cómo contener, en verdad, estas convulsiones de espacio y tiempo ya desencadenadas! ¿Qué atrás parece quedarse la deseable insularidad del mundo ideal de Tomás Moro ${ }^{49}$ El dominico español no tiene pelos en la lengua. La lógica de dominación se articula sin fingimientos, ni eufemismos ni hipocresías. Los llamados siete "justos títulos" incluyen, en esencia, el derecho a la predicación de la fe verdadera y el derecho al libre intercambio y libre comercio. Toda vez que algunos indios se conviertan al cristianismo, el establecimiento de alianzas con algunas de estas colectividades americanas legitima la intervención bélica en su defensa. Es el derecho de autodefensa. La "guerra justa" se convierte así, en toda puridad jurídica, en el acompañamiento discursivo que acredita la legitimidad al expansionismo europeo ya imparable. Si el expansionismo está visto, en el caso de Vitoria, desde una posición histórico-social de fuerza y privilegio, ${ }^{50}$ la formalización de conflicto (guerra) sigue siempre la causa formal del daño (iniuria) por parte de los agresores (los agresores son siempre los otros, por definición jurídica). Vitoria nunca descenderá de unos principios generales a barajar particularidades. La "guerra justa" aparece, pues, como posibilidad legítima no dentro de la formulación de ley natural, o empeño universalizador, sino dentro de la diferenciación de colectividades, o "derecho de gentes." Guerra justa es la explicitación de unas diferencias irreconciliables dentro de una pluralidad de colectividades (derecho de gentes) a su vez dentro de una globalización (la ley natural del orbe), que se puede desvirtuar o desnaturalizar (¿pero por cuánto tiempo?). La guerra justa es aquélla que no es causa, ya que "exige la reparación de una injuria recibida" (págs. 107 y 135) según la norma general que establece que "[e]s lícito repeler la fuerza con la fuerza" (pág. 111). Se trata de un legítimo derecho que compete a toda constituida república (el nivel individual es aquí inoperante). En 1539, la continentalidad americana nunca se fragmentará en repúblicas, únicas entidades políticas legítimas que, una vez violadas en su derecho, pueden vengar las injurias con todo lo que tengan a mano. En Vitoria, la mano obedece a la mente que no da mientes, al menos ordinariamente, al quehacer ordina-

49 Para una contextualización de estos primeros estiramientos de espacio y aceleramientos de tiempo, ver Braudel, Fernand: Civilization \& Capitalism 15th and 18th Centuries: Perspective of the World. Volume Three, New York, Harper \& Row Publishers, 1979, págs. 21-88.

50 Deseamos reconocer nuestra deuda para con Michel Foucault en su tratamiento de la noción de guerra como manifestación latente y pura de relaciones de fuerza. Es así que es necesario un cierto distanciamiento del discurso del filósofo-jurista en tanto que sujeto (pretendidamente) universal y totalizante o neutral, Genealogía del Racismo, Madrid, La Piqueta, 1992. 
rio del statu quo. Es así que podemos hablar de un indubitable principio de certidumbre en Vitoria en esta ley de obediencia al poder establecido. Dudas habrá, por supuesto, pero éstas serán como satélites alrededor del planeta terrestre de la cristiana autoridad imperial (incertidumbres cercan estas especulaciones universitarias al respecto del expansionismo europeo en América, pero mucho menos el quehacer diario de sus oficiales dentro de la maquinaria del Estado). ${ }^{51}$ Urdánoz ha aportado alguna valiosa información a propósito de las periódicas imposiciones de silencio a los dominicos de San Esteban por parte de Carlos V. Sedición estaría así peligrosamente a la vuelta de la esquina. Vitoria se retrotrae de estos peligrosos territorios (¿no lo hace la cultura represiva siempre?). Los ámbitos pedagógico-represivos, en los que Vitoria encuentra su circunstancia históricovital, dejan bien a las claras, al menos para el momento alboreal del XVl, que no se trata de posibilitar unos mecanismos hermenéuticos que promoviesen una hibridez o una trans-culturación con estas poblaciones americanas tan lejanas y cercanas a la vez, sino de todo lo contrario. ${ }^{52}$

Vitoria, muy al contrario de los apologistas actuales de los derechos humanos, construye sin lugar a dudas una ética imperial. La lógica de este derecho de sometimiento enuncia que, de nuevo sin eufemismos, si la guerra justa se gana, hay perfecto derecho - Vitoria sigue a San Agustín ${ }^{53}$ y a Santo Tomás de Aquino ${ }^{54}$ - al sometimiento de los vencidos al cautiverio (pág. 177) y a la esclavitud, acompañada de la exigencia de "rehenes, naves y todo cuanto sea indispensable (sin fraude ni dolo)" (págs. 135, 187). Los vencidos pasan así "de hombres libres a siervos nuestros" (pág. 189). Pueden ser castigados con la pérdida de territorio (pág. 195) y con la imposición de tributos (pág. 199). La puerta jurídica queda abierta ante la escalo-

51 En nuestro libro anteriormente citado, analizamos cuidadosamente el texto jurídico más ambicioso de Vasco de Quiroga, Información en Derecho (1535), donde se puede constatar una serie de propuestas de gobierno indiano toda vez que los derechos legítimos de dominación han sido puestos fuera de toda incertidumbre.

52 Vitoria nunca encontró motivos en su horizonte histórico de convertirse en un promotor de una deseable pluralidad pluricéntrica de tradiciones jurídicas. ¿Ha visto la historia del derecho (internacional) esto alguna vez? ¿Se consensúa la cultura represiva? Véase algunas de estas especulaciones en Prakash Sinha, Surya: Legal Polycentricity and International Law, Durham, Carolina Academic Press, 1996.

53 Nuestra edición ha sido, Concerning the City of God against the Pagans, London, Penguin Books, 1972. Los comentarios sobre la guerra justa se encuentran en págs. 216-224 y 860-880.

54 Nuestra edición ha sido, Summa Theologica, New York, Benziger Brothers Inc., 1947. El segundo volumen incluye la racionalidad de la guerra justa en la segunda parte (sección 40, págs. 13591363). Es aconsejable ver también el tratado sobre prudencia y justicia (págs. 1389-1704), especialmente sobre la noción de restitución, tan recurrente en Bartolomé de las Casas. 
friante posibilidad del exterminio total de los vencidos, aun cuando éstos se quieran declarar inocentes, en caso de que existiese algún tipo de peligro latente (págs. 179-183). La noción de "guerra justa" propuesta por estas Relecciones Indianas no desmerece un ápice ante la ferocidad teatral del maquiavelismo. ${ }^{55} \mathrm{La}$ atenuación de la clemencia para con los vencidos es, es verdad decirlo, deseable, si bien para Vitoria su uso será esporádico. El saqueo de una ciudad es lícito si la necesidad de la guerra mueve a ello (pág. 193). Además de la toma de Tenochtitlan (1521), en el primer año de Carlos V como emperador, podemos recordar el Saco de Roma (1527), ${ }^{56}$ sonrojante episodio para el defensor oficial del Cristianismo, y año de nacimiento del príncipe Felipe (1527-1598). ${ }^{57}$ El uso comedido de la fuerza quedará siempre, en las Relecciones de Vitoria, a merced de los envites de la contingencia política. La lógica de esta necesidad parece del todo impredecible desde las atalayas (¿o los espejismos?) de la generalidad de principios (recordemos al Ortega que "piensa al trasluz," tras Leibniz, la presunta preeminencia "fundamentalista" de los principios jurídicos, físicos, etc.). En realidad, se puede ver que la formulación de la "guerra justa" se circumscribe enteramente al juicio del vencedor. Guerra justa es la que se gana.

La sombra alargada de esta formulación romanizante de guerra, revivida por Vitoria, llegará a las playas americanas y las aulas universitarias novohispanas ya en el siglo dieciséis. La cosa no se quedará ahí. Desafiando toda longevidad, será retomada por la historiografía norteamericana decimonónica (Henry Wheaton) y rescatada oportunamente por J. B. Scott para los nuevos tiempos con los Estados Unidos como nuevo árbitro de dispares realidades de mundos encontrados. Esta formulación llegará a asentarse, de momento, en la sede última neoyorkina de las Naciones Unidas, pero sólo después de las tremendas convulsiones internacionales del siglo pasado..$^{58}$

55 Podemos recordar la tremebunda ocurrencia del duque Valentino, Cesare Borgia, incluida en el capítulo siete: la exhibición del cuerpo mutilado de Messer Remiro de Orco sobre una madera con un cuchillo ensangrentado al lado, en la plaza de Cesena, The Prince, editado por Harvey C. Mansfield, Chicago, The University of Chicago Press, 1985, págs. 29-30.

56 Valdés, Alfonso de: Diálogo de las Cosas Acaecidas en Roma, edición preparada por José Luis Abellán, Madrid, Editora Nacional, 1975.

57 El Saco de Roma es hermosamente descrito por la prosa humanística de Alfonso de Valdés. Véanse las noticias del cronista benedictino Sandoval, Prudencio de: Historia de la Vida y Hechos del Emperador Carlos V, Madrid, Biblioteca de Autores Españoles, 1955, págs. 451-457.

58 Los artículos 40-51 de la Carta de la Organización de las Naciones tipifican varios de los procedimientos para la militarización de la paz. Aun sin usar la expresión de guerra justa, se legitima la obligatoriedad, disponibilidad y el uso, supuestamente conjunto y/o mayoritario por parte de los miembros participantes, de la fuerza armada para contrarrestar el quebrantamiento de la paz, ibidem, págs. 35-39. 


\section{Rápidas conclusiones}

El tiempo histórico que produce una figura intelectual como la de Francisco de Vitoria se debe reconstruir como una falla, aún leve si se quiere, en las longevas formas medievales de organización y sociabilidad del saber que deberán encarar los momentos iniciales de una convulsiva sincronización de espacios y temporalidades dispares, o lo que podemos llamar la Modernidad. ${ }^{59}$ Vitoria tenía 6 años en 1492, 35 cuando Cortés conquista la capital azteca (1521), 53 cuando expuso en las aulas salmantinas sus Relecciones Indianas (1537-9), y 56 durante las importantes deliberaciones de Valladolid (1542-3). El dominico español falleció sin poder asistir, ya convaleciente, al Concilio de Trento (1545-1563). Es un hombre de su tiempo - convulso, novedoso- como nosotros lo somos del nuestro. El elemento "indio" en las Indias Occidentales es lo que trae las Relecciones Indianas de Vitoria a nuestro presente con toda la ortodoxia histórica de sus afirmaciones y titubeos, silogismos, conciliaciones y repudios. Este ensayo ha analizado algunas de estas tensiones o agonías propias de este intelectual dentro del crisol de la "trans-modernidad," según la nomenclatura de Enrique Dussel.

El saber viajero y sumamente influyente de Vitoria en su tiempo histórico no es cabalmente un saber burocrático, ni una pedagogía de educación de príncipes como el de Saavedra y Fajardo, ni un saber humanista como el de Nebrija o el de Ginés de Sepúlveda. ${ }^{60}$ Sin embargo, el saber de Vitoria formará, "de oídas" si se quiere, a burócratas y letrados, a príncipes, cronistas y cortesanos. Llegará antes de que acabe el dieciséis donde él no llegó: a Nueva España (fray Alonso de la Vera Cruz, Vasco de Quiroga) y las costas chilenas del Pacífico. ${ }^{61}$ Es un saber cosmopolita, o si se quiere trasterrado,

59 Además de Braudel, nuestra visión de este período se enriquece con los hallazgos de Wallerstein, Immanuel: The Modern World System. Capitalist Agriculture and the Origins of the European World-Economy in the Sixteenth Century, New York, Academic Press, 1974. Dentro de la articulación de centro-periferias, es fundamental para nosotros el trabajo panorámico de Arrighi, Giovanni: The Long Twentieth Century, New York, Verso, 1994.

60 'Humanista' significa para nosotros un saber situado en los aledaños del monasticismo. Se trata de un quehacer intelectual seducido por la restauración grecolatina, inmerso en una reconstrucción filológica de delicado equilibrio "secular" entre las instancias de poder cortesano, la Patrística y el aristotelismo. Seguimos en esto a Rico, Francisco: El Sueño del Humanismo: De Petrarca a Erasmo, Madrid, Alianza Universidad, 1993. El libro panorámico de Gil Fernández antes citado es también fundamental.

61 Para un rastreo inicial, consúltese Martínez Busch, Jorge: La influencia de Fray Francisco de Vitoria en Chile 1550-1560: Apuntes para una Historia, Santiago, Zig-zag, 1993. 
porque es un saber prestigioso, de ágora universitaria, de trascendencia colectiva. La cultura represiva de Vitoria no es, ni quiso ser nunca, detallada etnografía. Estas Relecciones no evidencian ningún indicio por desmembrar o particularizar, existencial o emocionalmente, esa totalidad llamada "indios" dentro de las Indias Occidentales. La cosa jurídica no va por ahí. No es este saber incómodo un historicismo existencialista. ¿Lo son los vuelos especulativos de la práctica represiva alguna vez? Su matriz no se concibe sin un fuerte prejuicio racionalista que se predica sin fisuras, a medio y largo plazo, entre creencia y raciocinio (fe y razón). Difícilmente admiten estas Relecciones Indianas una pluralidad de "lecturas", porque lo que está aquí en juego, es la singularidad universalizante de racionalidad neotomista en un horizonte que no concibe lo no-cristiano como una alternativa viable (razón es "pre-juicio racionalista" de coincidencia de vida-mundo y razón según la formulación cristiana de colectividades monástico-dominicas en prácticas de conocimiento formales o universitarias). Si la vida-mundo se está planetarizando en el dieciséis, Vitoria es un intento primero por dar cuenta represiva de algunos de estos estiramientos y aceleraciones, tensiones y distensiones, divergencias y convergencias.

La para-literatura asociada con el nombre singular de Francisco de Vitoria debería incomodar en algo los rápidos acomodos de una sensibilidad letrada y libresca (por otra parte, sensibilidad ya desfasada ante la 'deshumanizante' digitalización de saberes en detrimento palpable de las 'humanidades'). Esta para-literatura administra, ordena, clasifica la realidad transatlántica, o al menos lo intenta. La cultura represiva intentará siempre apresar la plasticidad o historicidad de variopintas formas humanas, inteligibles o no. Vitoria representa, al menos para nosotros, una de las mejores atalayas a las que la imaginación histórica se puede subir para intentar vislumbrar algunas de estas panorámicas oficiales del siempre novedoso siglo dieciséis. ¿Queremos recordar u olvidar a Vitoria? ¿Escribimos para intentar vislumbrar unas panorámicas humanas heterogéneas de plazos largos o no tenemos más remedio que acotar espacios de certeza a corto plazo contra la destemplanza y la desmemoria, al igual que el protagonista de la película Memento de Christopher Nolan? Escritura contra el tiempo, volición de la memoria... Pero estas son cuestiones mayores.

¿A cuenta de qué necesitaron Wright, Wheaton y J.B. Scott a Vitoria si no fue para defender unos intereses estadounidenses? ¿De qué sirvió este neo-escolasticismo si no para amortiguar, desvirtuar o contener algunas de las demandas democráticas que se estaban produciendo entre medias del 
fascismo y el socialismo? M. Grice-Hutchinston ha defendido la continuidad entre el pensamiento económico neoescolástico español y el liberalismo económico. Lo cual equivale a decir que la importancia de Vitoria no estaría tanto en la formulación más o menos plausible de unos derechos de dominación y subordinación (los títulos de conquista) cuanto en los esbozos de lo que se da en llamar el libre comercio. En otras palabras, las apelaciones vitorianas a la legitimidad del ius predicandi, dentro de la presunta universalización del cristianismo, se deben yuxtaponer al ius peregrinandi, movilidad y "transhumancias" (la palabra es de Passolini) que el capital necesita para mantenerse con vida. La dimensión mediática del capital sigue con nosotros, más vigoroso, omnipresente, imprevisible y dúctil hoy que en los tiempos antiguos de Vitoria. Es el capital la fuerza motriz que desplaza los suelos, posibles e imposibles, de la creencia hacia las antesalas del fingimiento o el cinismo. ${ }^{62} i Y$ no digamos la utópica creencia en otra cosa que no sea él mismo en el tiempo de pretérito o de futuro perfectos! La modernidad 'está' indisolublemente ligada con estos horizontes alboreales del capitalismo. Vitoria 'está' colectiva e inconscientemente en dicha modernidad con todo su cristianismo neotomista. J. B. Scott, vinculado a la filantropía del industrial escocés Andrew Carnegie, rescata a Vitoria del olvido de los tiempos y lo aúpa, junto con la doctrina Monroe, sobre el pedestal de las naciones del mundo con la congruencia propia de unos intereses creados. ¿Estaba la Salamanca de 1923 en condiciones de desmentir a éste? ¿Lo está hoy día? "De la mutilación de las estatuas/a veces surge la belleza," que diría el poeta salmantino ${ }^{63}$ ¿Qué podemos hacer con las ruinas de la historicidad que tenga valor memorable para una comunidad internacional en relación con los regímenes de vida y verdad?

Queda para otra ocasión el análisis crítico de M. Grice-Hutchinston, vis-à-vis de los estudios de $\mathrm{R}$. Carande ${ }^{64} \mathrm{y}$ de otros, ${ }^{65} \mathrm{a}$ propósito de una lec-

62 Al hilo de creencia, escepticismo y cinismo, véase "Ethics is the Original Philosophy, or the Barbarian Words Coming From the Third World: An Interview with Enrique Dussel", Boundary 2, vol. 28, núm. 1, spring 2001: págs. 19-73 [40-46].

63 "De la mutilación de las estatuas/a veces surge la belleza, de los/capiteles truncados cuyo acanto/cayera en la maleza entre el acanto... un verdor sorprendido/por la primera lluvia que conoce-: posible/perfección del azar que nada tiene/que hacer para ser símbolo de todo/lo que se quiera;" Núñez, Aníbal: Obra Poética l, Madrid, Hiperión, 1995, pág. 175.

64 Estudios de Historia: 1. Temas de Historia de España, Barcelona, Editorial Crítica, [1969 \& 1978] 1989, y El Atlante Patético (Otros Estudios sobre Carlos V), Mérida, Badajoz, Junta de Extremadura, 1997.

65 Al terminar este trabajo cayó en nuestras manos la antología El Pensamiento Económico en la Escuela de Salamanca editado por Francisco Gómez Camacho y Ricardo Robledo, Salamanca, Universidad de Salamanca, / Fundación Duques de Soria, 1998. 
tura histórica del entramado económico que resulta de los postulados jurídicos de Vitoria y de la Escuela de Salamanca. ¿Pecamos de economicismo en esta sugerencia inicial de que tal vez tengamos que desembocar la vigencia actual de Vitoria en su compañero de cátedra, Martín de Azpilcueta (1492-1586)? ${ }^{96}$ Habrá que seguir más cuidadosamente las hipótesis de funcionamiento del dinero y el crédito dentro de los mecanismos contractuales coloniales. ${ }^{67}$ De momento, nos parece suficiente esta hipótesis de elección de Vitoria por parte de autores estadounidenses como una estrategia de diversión de peligros mayores allende las fronteras de una Península Ibérica, ya durante la visita de J.B. Scott, con un pie en la guerra civil. Esta noción de "guerra" en Vitoria es, desde luego, resbaladiza y ciertamente brutal. La guerra justa es la que se gana y el ganador es el que dicta las condiciones de reparación de la injuria causada por el enemigo sin que haya, en el horizonte inmediato de Vitoria, ningún testigo o juez imparcial. Y punto final. No hay "peros" discernibles en las Relecciones Indianas, ni posicionamientos neutrales. $i$ "Paz" del primer mundo asentada en el privilegio y la fuerza significa qué para otros mundos? ${ }^{68}$ Este parece ser uno de los límites de la cultura represiva, de por sí discursividad oficial y práctica institucional. Estos otros mundos, llamémoslos indianos, significan, al menos para las Relecciones Indianas de Vitoria, la posibilidad incierta de unos saberes contrarios a la historia de la dominación europea. ¿Se equipara la cultura represiva siempre con saber institucional? ¿Se deben tomar los papeles institucionales al pie de la letra? ¿Es el papel del derecho papel mojado y letra muerta sin ninguna "otra cosa"? ¿Secamos estos papeles mojados? ¿Intentamos revivir estas letras muertas? ¿Qué sería un saber noinstitucional o para-institucional? De nuevo, cuestiones mayores que próximos estudios irán contestando de alguna manera.

Dejémoslas ahí de momento en relación a las primeras tensiones de la modernidad transatlántica. Estas Indias con todos sus "indios" constituyen

66 Comentario Resolutivo de Cambios, introducción y texto crítico de Alberto Ullastres, José M. Pérez Prendes y Luciano Pereña, Madrid, CSIC, 1965.

67 Calderón, Francisco R: Historia Económica de la Nueva España en tiempo de los Austrias, México: Fondo de Cultura Económica y Economía Latinoamericana, 1988. Calderón incluye una síntesis apretada de las Relecciones Indianas de Vitoria de una manera tal vez un tanto textualista, o demasiado apegada a la explicitación de sus postulados, los cuales son considerados "legislación protectora de los indios," más eficientes que Las Casas, págs. 114-6, 118, 156, 184, 254, 255, 621-622.

68 Al hilo de la formulación de centro y periferias de Wallerstein, podemos mencionar la geografía de los parcelamientos de saberes delineada por Pletsch, Carl E.:"The Three Worlds, or the Division of Social Scientific Labor, circa 1950-1975," Comparative Studies in Society and History, Vol. 23, Num. 4, Oct. 1981, págs. 565-590. 
la brutal novedad de lo impredecible, al menos para las primeras generaciones entre las que Vitoria ciertamente se encontraba. El espacio virtual de las Indias Occidentales tiene poco que ver con la visión panamericanista de J.B. Scott y el mundo de éste ya no es el nuestro. Estas Indias - heterogeneidad del hispanismo internacional digámoslo claramente- pueden representar más bien lo no enteramente asimilable a la práctica para-lógica represivo-jurídica, que es sólo la punta del iceberg, si se quiere, de una abstracción de inclusiones y exclusiones de seres humanos de los bienes sociales disponibles o futuribles. Es claro que la racionalidad neotomista, de por sí preñada de incómodos silogismos, no da cumplido razonamiento de la historicidad moderna proto-capitalista en la que se asienta. Es por eso que no nos debemos quedar, como el asno embobado ante la zanahoria que le cuelga entre los ojos bizcos, en las explicitaciones más o menos contradictorias de estas textualidades volátiles de Vitoria, que por otra parte él no escribió. Este exceso de racionalidad universitaria o formal es lo que hemos querido apuntar con la sugerencia, extraída de Lalinde-Abadía, de paralogismo como elemento no marginal ni tangencial de la práctica, académica o no, de la cultura represiva. Qué hacer y qué no hacer con las dimensiones paralógicas, no está nada claro; por de pronto circunscribirlas en su circunstancia histórica. La nuestra, claro, tendrá también las suyas, que muy posiblemente no podamos ver con claridad.

Si no nos unimos a las celebraciones de nuestros antepasados de principios del siglo veinte, tampoco creemos que debamos sentarnos a la vera de las plañideras de los debilitamientos nacionales o nacionalistas. ${ }^{69}$ Estos debilitamientos tal vez abran unas puertas a un mundo novedoso (¿o es que nos creemos que los orígenes nacionales necesariamente nos tienen que proporcionar la felicidad para el futuro?). La primera modernidad transhispana no es la república de Miranda, que diría Luis Buñuel. ${ }^{70}$ No somos ya como nuestros abuelos decimonónicos, ¡menos mal!, y la brutal caída de dimensiones históricas, no sólo de Vitoria y de su circunstancia del dieci-

69 Véase una convincente geografía de ubicaciones históricas a propósito de la "doble inversión postcolonial" de la Península Ibérica en el contexto hegemónico estadounidense — dentro y fuera del mundo académico, en Gabilondo, Joseba: "Estudios culturales: Travestismo y Novela Terrorista, Masoquismo Femenino y Deseo en la Literatura Vasca Postnacional," El Hispanismo en los Estados Unidos: Discursos Críticos-Prácticas Textuales, Madrid, Visor, 1999, págs. 231-254 [234-7].

70 Para una contextualización del hispanismo, con un pie en el otro lado del Atlántico, véase Pérez Montfort, Ricardo: Hispanismo y Falange; Los Sueños Imperiales de la Derecha Española, México, Fondo de Cultura Económica, 1992. Véase también el excelente libro de Varela, Javier: $L a$ Novela de España: Los intelectuales y el Problema Español, Madrid, Taurus, 1999. 
séis, se lleva con sus corrientes desordenadas todos los cosmopolitanismos fáciles y los localismos frágiles. Entre medias, estamos mientras tanto tirando de las continuidades y de las discontinuidades de las generaciones humanas que nos han precedido y que nos seguirán. ¿A qué lugares - de pasado y de futuro- vamos a construir conocimientos? ¿Erigimos estatuas a la nada de nuestros miedos e ignorancias? ¿Nos maravillamos, como papamoscas, de los elogios de J.B. Scott a Vitoria? ¿Dónde vamos, de dónde venimos, para contrastar las diversas teorías, las letras, las historias de la historia?

Vitoria nos ayuda a propiciar algunos de estos desdibujamientos de lo propio y lo ajeno. Su para-literatura es norma del dieciséis que va a poner a prueba, sin duda, nuestros mejores deseos interpretativos. Lo que se ve de Vitoria - apretada letra en español o en inglés contenida en libro viejono es lo que fue. Y lo que fue llega a nuestro regazo sólo a través de la mediación de estos textos viejos no amables con el interés del gran público no lector. La cultura represiva nunca participa, por cierto, de este tipo de amabilidad. Comenzamos diciendo que Vitoria es hoy un hombre invisible. Tal vez fuera mejor decir que es casi ilegible. Los indios, esa tremenda dimensión humana de atlántidas sumergidas, lo hacen legible. La forma de la letra y la cultura represiva se nos antojan circunstancia ineludible, ayer como hoy, para la expresividad de una sociedad que se atreva a negar colonialidades en un futuro próximo. Pero antes tendremos que aprender a conjurar algunos de estos mal aprendidos miedos, desidias y olvidos para con la heterogeneidad que somos nosotros para otros y para nosotros mismos. En definitiva, hemos ido a Vitoria a ganarnos la vida, o por lo menos lo hemos intentado. 